\title{
Job loss and first pregnancy in young women
}

The integration of women into the workforce in Britain was accelerated by the shortage of male labour during both world wars. In 1965 Gavron found that $80 \%$ of working class women continued in paid employment even after marriage. ${ }^{1}$ What happens, however, when a young wife is suddenly made redundant and finds, in a harsh economic climate such as we have now, that her chance of finding other work is small? Is the decision to start a family postponed or promoted? In this small study we report on a group of young married women facing such a dilemma. The null hypothesis for testing was that the incidence of first pregnancy during the months after compulsory redundancy is no different from that found in the whole population of contemporaneous married, nulligravid women.

\section{Subjects, method, and results}

During 1982, 302 workers were made redundant when a local factory closed. ${ }^{2}$ Of these, 103 were women registered as patients in our practice; 10 were married and aged below 30 at the time of redundancy (only $6 \%$ of women in our practice conceive their first born when older than this). Two had been under investigation for primary infertility since 1979 and were omitted from the study. Of the
Fisher's exact test, however, we found a significant difference between the proportion of women in each group who conceived within the study period $(p=0 \cdot 02)$. The disparity was due to the increased tendency of the women who had been made redundant to start a family soon after the notification of redundancy.

\section{Comment}

Motherhood may seem an attractive proposition when 906000 other women are seeking paid employment, as was the case in Great Britain in $1982,{ }^{4}$ and our results suggest that this is so for a high proportion of newly redundant young women. The primigravida recently thrown out of work cannot overlap the dual roles of worker and expectant mother and is denied a period of helpful adaptation at a costly and stressful time.

We would like to pose two questions. If large numbers of unemployed women are allowing themselves to fall pregnant by a process of "negative" family planning - "I may as well..."-will it precipitate an increase in rejection of the infants, puerperal mental illness, and child abuse? Secondly, are not these same women, by becoming pregnant, inadvertently disguising the real extent of female unemployment?

Details of nulligravid women born during 1955-62, registered with the practice and married for a minimum of two years on 19 May 1982

\begin{tabular}{lccc}
\hline & $\begin{array}{c}\text { Median age } \\
\text { (years) }\end{array}$ & $\begin{array}{c}\text { Median duration of } \\
\text { marriage (years) }\end{array}$ & $\begin{array}{c}\text { No who conceived during } \\
\text { May 1982 to January 1984 }\end{array}$ \\
\hline $\begin{array}{l}\text { Women made redundant }(\mathrm{n}=6) \\
\text { Control group }(\mathrm{n}=54)\end{array}$ & 23 & 4 & 4 \\
\hline
\end{tabular}

remaining eight married women under 30 , one was already pregnant and one was being treated for reactive depression after marital breakdown; these two were also excluded.

Thus six of the women were under 30 and married (for two to seven years) but still nulligravid at the time of the announcement of the redundancies (19 May 1982). All six were using oral contraception at that time. Two of the women continued to use this contraceptive technique, but the others withdrew from the pill and conceived within 14 months.

As a control group we studied all other women in the practice who had been married for a minimum of two years, had been born during 1955-62 inclusive (as had the study subjects), and were yet to conceive their first child. Any of the control women already under investigation for infertility or for whom there was any intimation of serious marital disharmony were omitted.

The 21 months May 1982 to January 1984 inclusive were adopted as the comparative study period on the basis of the work of Vessey $e t$ al. ${ }^{3}$ They showed that only a further $7 \cdot 6 \%$ of 1174 nulligravid women conceived later than 21 months after stopping oral contraception. The incidence of first pregnancy during the study period was then calculated for both the unemployed and control groups (table).

Using the Mann-Whitney U test, we found no significant differences between the median ages or the median durations of marriage of the two groups. Using
We thank staff of the personnel department of C and T Harris (Ipswich) Ltd for their help and also the staff at Calne Health Centre. This work was supported by a grant from the Scientific Foundation Board of the Royal College of Genera Practitioners.

1 Gavron H. The captive wife. London: Routledge and Keegan Paul, 1966.

2 Beale N, Nethercott S. Job-loss and family morbidity: a study of a factory closure. $\mathcal{F} R$ Coll Gen Pract 1985;35:510-4

3 Vessey MP, Wright NH, McPherson K, Wiggins P. Fertility after stopping different methods of contraception. BrMed f 1978; i:265-7.

4 Hawkins K. Unemployment. Harmondsworth, Middlesex: Penguin, 1984.

(Accepted 9 fanuary 1986)

The Health Centre, Calne, Wiltshire SN11 8NQ

NORMAN BEALE, MA, MRCGP, general practitioner

SUSAN NETHERCOTT, MSC, statistician

Correspondence to: Dr Beale.

\section{Results of delayed follow up of abnormal cervical smears}

Recently we analysed the outcome (to October 1983) in 1062 women who had a first report of abnormal cervical cytology in $1981 . .^{\text {' Satisfactory follow }}$ up was documented for only $628(59 \%)$, although a further $275(26 \%)$ had one subsequent normal smear; 43 women had not been asked to have a further smear, and seven had refused an invitation for a further smear. Further efforts were made to contact these 50 women, and we present the results up to October 1985, a minimum of three years and eight months after the first abnormal smear. In all these patients the initial smear had shown mild or moderate atypicalities. Patients with highly atypical cells had all been satisfactorily followed up as a result of laboratory initiatives.

\section{Patients, methods, and results}

Intensive searches were carried out using the records of the cytology department, City Hospital, Nottingham, and the corresponding histopathology records, and by correspondence with the clinician who first detected the abnormal smear and to relevant general practitioners.

Among the 50 patients the current state remained unknown for two who had left the district and seven who had not had a further cervical smear identified in the laboratory by October 1985 . The remaining 41 patients had had a follow up smear. Of these, 12 patients $(29 \%)$ had a histological abnormality of cervical intraepithelial neoplasia grade II or worse: three had grade II and seven grade III lesions, one had a microinvasive carcinoma, and one had stage I invasive carcinoma; for both these last two patients first follow up was three years and 10 months after the previously abnormal smear. The proportion of abnormal histological findings was $25 \%$ in those followed up less than three years after the first abnormal smear and 33\% in those from whom biopsy samples were taken more than three years later (table). Follow up was achieved in all seven patients who had refused initial invitations; of these, two showed cervical intraepithelial neoplasia grades II and III, a similar proportion to that in patients who had not originally received invitations for follow up.

\section{Comment}

These results show that women who have had one cervical smear showing mild or moderate atypicality, and who have not been promptly followed up, have a $29 \%$ chance of harbouring a lesion of cervical intraepithelial neoplasia 